INTRODUCTION 


\title{
THE DYNAMICS OF RITUALS IN THE ROMAN EMPIRE
}

\author{
Angelos Chaniotis
}

\section{Ritual Displacement ${ }^{*}$}

The Roman envoys sent to settle affairs in the East after Rome's victory over Macedonia in $167 \mathrm{BC}$ must have been shocked at the spectacle that awaited them in Nikomedeia, the capital of the kingdom of Bithynia. ${ }^{1}$ They expected to meet Prusias, king of Bithynia, a friend and ally of the Roman people. But the man who appeared in front of them had his head shaved and was wearing the attire of a Roman freedman: a white cap, toga, and boots. The king, in this 'theatrical costume' ( $\delta 1 \alpha \sigma \kappa \varepsilon v \eta$ ), stretched out his right hand to the envoys and greeted them with the words: "Behold your freedman, who is willing to endear himself to you and emulate all your customs." Polybius, our source, describes another bizarre scene with the same protagonist, this time in Rome:

When he came to the entrance that leads to the senate, he stood at the little door facing the council and, lowering both his hands to the ground, he prostrated himself in front of the threshold and those who were seated and exclaimed: 'hail, you saviour gods!'

In Nikomedeia, Prusias performed a Roman social ritual, in Rome a Greek religious one: lying entirely flat on the ground in front of a divinity, a practice known both from literary sources and from

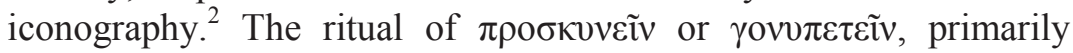
attested in connection with saviour gods, was often associated with supplication and primarily performed by women. By adopting it, Prusias assumed the passive role of a suppliant and a woman. The ritual at Nikomedeia was intended to make the Romans into Prusias' patrons; the ritual in Rome transformed the building of the senate

\footnotetext{
* I would like to thank Elizabeth Meyer and Ted Lendon for correcting my English and for their critical remarks.

${ }_{1}^{1}$ Polybius 30.18-19; cf. Livy 45.44.

${ }^{2}$ F. van Straten, 'Did the Greeks Kneel before their Gods?', Bulletin Antieke Beschaving 49 (1974), 159-189.
} 
into a Greek temple, the senators into gods, and the king into a suppliant. The aim of both rituals was to establish and express a reciprocal relationship of dependence: as a libertus, Prusias was obliged to obey the Romans, obliging them in return to protect him; by declaring the Romans saviour gods, he asked them not to stop manifesting their rescuing power. Both rituals involved the use of the appropriate costume and body language.

In both cases, traditional rituals were displaced from their usual contexts: the ritual behaviour of a man who has just been manumitted was imitated by a king, who may have used the attributes of a freedman (cap, toga, and boots), but lacked his most important legal right: Roman citizenship. The ritual behaviour of a man who approaches the statue of a god in a temple was transferred from a temple to the curia, from the gods to the senators of Rome.

Prusias' ritual experiments were criticised by his contemporaries and ultimately failed to guarantee Rome's protection. But they did make a lasting impact in another respect. Although his behaviour in Nikomedeia did not find imitators among contemporaries, for modern historians it became the paradigmatic behaviour of the client king. His behaviour in Rome may have shocked his contemporary audience, but 150 years later the Roman senate was indeed worshipped in the Greek East as a deity (theos Synkletos), ${ }^{3}$ leaving the Greeks as puzzled over the gender of the new god (senatus is masculine, but $\sigma 0 ́ v \kappa \lambda \eta \tau o \varsigma$ feminine) as medieval theologians were over the gender of the angels.

In these two episodes two worlds met, two worlds with their different cultural traditions, but also two different states engaged in a complex power play. Significantly, Prusias, a Hellenised king and not a religious expert, chose to express the relationship between his kingdom and Rome symbolically through rituals, by adopting a foreign ritual and by transferring a local ritual from one context, that of the worship of the gods, to another, that of the political relations with a hegemonic power. I have chosen these episodes of Hellenistic history as an introduction to the complex phenomenon of ritual dynamics in the Roman Empire because they encapsulate two essential features of this phenomenon - ritual transfer and the adaptation of rituals in order to demonstrate changes in relationships

${ }^{3}$ D. Kienast, 'Der heilige Senat. Senatskult und kaiserlicher Senat', Chiron 15 (1985), 253-282. 
- and because they date to a relatively early phase of Roman expansion. I have chosen these episodes also because they do not come first to one's mind in connection with the subject of ritual dynamics.

The Roman Empire is a model for understanding the changing functions of rituals in changing environments. The enormous spatial dimensions of the Empire; its complex multicultural character; the unprecedented mobility of its population; the contrasts between the unified administrative system and local autonomy, between old traditions and new hierarchical structures and institutions, between centre and periphery, and between the local and universal; and the interplay between tradition, innovation, and revival - all these are factors that affected the operation of rituals in religion, politics, and society.

A few characteristic cases, taken primarily from the Roman East, will serve to exemplify some aspects of the dynamics of rituals in the Roman Empire: agency, transfer, emulation, and competition. I shall discuss only instances of ritual dynamics that were caused by the existence of the Roman Empire, and not cases that merely occurred in the Empire without being altered or generated by the Empire. It will soon become clear that I am not viewing this phenomenon from the perspective of the capital but from that of the provinces. This, of course, does not mean that Rome itself did not experience ritual dynamics. On the contrary: from the very beginning of the expansion that ultimately created the Empire, the Romans were continually confronted with the rituals of their allies and their enemies and confronted them with their own, e.g., when they took oaths and declared war, when they sacrificed before a battle and practiced divination, when they received envoys or saw their successful generals being declared gods in the Greek cities. This clash of cultures became, indeed, the subject of anecdotes, such as the one narrated by Livy (35.48.12): ${ }^{4}$ In $192 \mathrm{BC}$ an Aitolian representative accused the Roman general Flamininus of having done nothing in the recent war against Philip V of Macedon but "take auspices and sacrifice and pronounce vows in the front like some little sacrificial

\footnotetext{
${ }^{4}$ R. Parker, 'Sacrifice and Battle', in: H. van Wees (ed.), War and Violence in Ancient Greece (London 2000), 301; A. Chaniotis, War in the Hellenistic World: A Social and Cultural History (Oxford 2005), 160.
} 
priest," while the Aitolians were risking their lives and confronting the real danger in battle.

New rituals were introduced in Rome - Dionysiac rituals, for example - which immediately became very popular, threatening public order and traditional religion, and making measures for their control necessary. ${ }^{5}$ After Actium, the most important new factor in the Roman Empire was the emperor. The existence of the emperor had consequences both for social and political rituals and for the practice of religion in Rome. I mention the efforts of the first princeps to reinforce traditional religion, including traditional rituals, and the way in which the establishment of the principate affected the celebration of the triumph and the organisation of spectacles by the Roman elite. ${ }^{6}$ The establishment of the principate introduced new ritualised forms of communication between subjects and emperor, for example the celebration of the adventus of the emperor in a city, the ritualised dispatch of embassies ${ }^{8}$ the oath of loyalty, ${ }^{9}$ and the congratulatory rituals of cities upon the accession of a new

\footnotetext{
${ }^{5}$ J.-M. Pailler, Bacchanalia. La répression de 186 av. J.-C. à Rome et en Italie: vestiges, images, tradition (Rome - Paris 1988).

${ }^{6}$ E.g., M. Beard, The Roman Triumph (Cambridge, Ma. 2007).

${ }^{7}$ J. Lehnen, Adventus Principis. Untersuchungen zu Sinngehalt und Zeremoniell der Kaiserankunft in den Städten des Imperium Romanum (Frankfurt 1997); S. Benoist, 'Le retour du prince dans la cité (Juin 193 - Juillet 326)', Cahiers du Centre Gustave Glotz 10 (1999), 149-175; id., Rome, le prince et la cité. Pouvoir impérial et cérémonies publiques (Ier s. av. J.-C. - début du IVe s. ap. J.-C.) (Paris 2005); M. Vitiello, 'Nuove prospettive sull'adventus in età imperiale', Mediterraneo Antico 3.2 (2000), 551-580. For the reception of Roman generals and envoys in Hellenistic Athens, see É. Perrin-Saminadayar, 'L'accueil officiel des souverains et des princes à Athènes à l'époque hellénistique', Bulletin de Correspondance Hellénique 128-129 (2004-05) [2006], 351-375.

${ }^{8}$ See now the new decree of Maroneia concerning future embassies to the emperor (SEG LIII 659; $A E$ 2003, 1559) and the discussions by K. Clinton, 'Maroneia and Rome: Two Decrees of Maroneia from Samothrace', Chiron 33 (2003), 379-417, with an addendum in Chiron 34 (2004), 145-148; M. Wörrle, 'Maroneia im Umbruch. Von der hellenistischen zur kaiserzeitlichen Polis', Chiron 34 (2004), 149-167; id., 'La politique des évergètes et la non-participation des citoyens. Le cas de Maronée sous l'empereur Claude', in: P. Fröhlich - C. Müller (eds.), Citoyenneté et participation à la basse époque hellénistique. Actes de la table

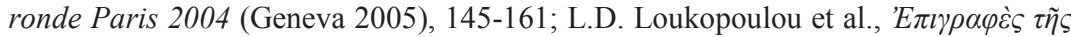

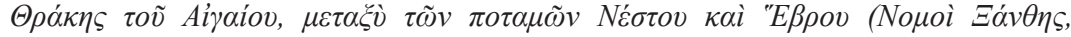

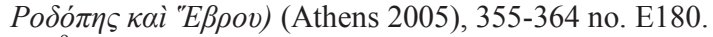

${ }^{9}$ H. Cancik, 'Der Kaiser-Eid. Zur Praxis der römischen Herrscherverehrung', in: H. Cancik - K. Hitzl (eds.), Die Praxis der Herrscherverehrung in Rom und seinen Provinzen, Akten der Tagung Blaubeuren 2002 (Tübingen 2003), 29-45.
} 
emperor. ${ }^{10}$ In these cases we are dealing not with the invention of new rituals but with the adaptation of pre-existing models.

\section{Ritual Agency}

The coming of the Romans often brought with it striking changes in ritual agency, i.e., in the nature of the authority by which the performance of rituals was supervised, negotiated, established, renewed, expanded, abolished, collated, changed, and explained. Until the coming of Rome, all this was an internal affair of the Greek communities. The treatment of rituals was not a simple matter; it involved complex negotiations within the community, between ritual experts and the assembly, between communities, between a community and a confederation, and between a community and its gods (especially by means of oracles). ${ }^{11}$ Nevertheless, it was an internal Greek affair. Roman expansion first made the Roman arbitrators in disputes - including disputes that affected religious matters -, and eventually made Roman authorities (the emperor and the provincial governor) judges, and the ultimate authorities who approved certain types of ritual practices.

My first example is that of Roman arbitration in religious disputes. The sanctuary of Sarapis on Delos faced local opposition from the very beginning of its existence. Around $200 \mathrm{BC}$, a temple was built only after the priest had defeated his opponents in a lawsuit. ${ }^{12}$ Some time later, a new conflict occurred between the priest of Sarapis and the Athenian authorities in Delos. As we may infer from an inscription, for which two different dates have been proposed (c. 166-164 and c. 58 BC), ${ }^{13}$ the Athenian authorities had

${ }^{10}$ T. Ritti, 'Documenti adrianei da Hierapolis di Frigia: le epistole di Adriano alla città', in: S. Follet (ed.), L'hellénisme d'époque romaine. Nouveaux documents, nouvelles approches (Ier s. a. C. - IIIe s. p. C.). Actes du colloque international à la mémoire de Louis Robert, Paris 2000 (Paris 2004), 309-311.

${ }^{11}$ See, e.g., R. Parker, 'What are Sacred Laws?', in: E.M. Harris - L. Rubinstein (eds.), The Law and the Courts in Ancient Greece (London 2004), 57-70; for the Imperial period, see A. Chaniotis, 'Negotiating Religion in the Cities of the Eastern Roman Empire', Kernos 16 (2003), 177-190.

${ }^{12}$ H. Engelmann, The Delian Aretalogy of Sarapis (Leiden 1975). Cf. H. Siard, 'La crypte du Sarapieion A de Delos et le process d'Apollonios', Bulletin de Correspondance Hellénique 122 (1998), 469-486.

${ }^{13}$ I.Délos 1510; Syll. ${ }^{3}$ 664; R.K. Sherk, Roman Documents from the Greek East: Senatus consulta and epistulae to the Age of Augustus (Baltimore 1969), no. 5. See 
forbidden the priest to open the sanctuary, which was probably at the time a private one. The priest protested in Rome, successfully, and returned to Athens with a senatus consultum, which allowed him to operate the sanctuary as in the past. The Athenian authorities had to comply.

A second example of the direct involvement of Roman power in ritual matters is the review of the claims of Greek sanctuaries to asylia in $22 / 23 \mathrm{CE}^{14}$ The term asylia had a variety of meanings, ranging from the inviolability every sanctuary enjoyed and the prohibition of reprisal as agreed between two communities, to the personal inviolability, guaranteed by a foreign city, of an individual from reprisal. ${ }^{15}$ In a narrower sense, in the Hellenistic period asylia designated the claim of inviolability made by certain sanctuaries and recognized by kings, cities, and confederations. Such inviolability goes back to an early perception of sacred space and supplication: by coming into physical contact with a sacred place the suppliant was incorporated into the sanctity of the place and could not be harmed or dragged away. In the Hellenistic period, ubiquitous wars presented a clear danger to life, personal freedom, and property, both private and public. They made the journeys of pilgrims, athletes, and performers dangerous, and threatened to interrupt the regular course of religious life and the celebration of festivals. Many cities officially declared their sanctuaries inviolable, often after an oracle; in some cases they even dedicated the entire city and its territory to a god, thus claiming inviolability for it by putting it under the divine protection. ${ }^{16}$ For the Greeks, then, asylia was connected with the ritual of supplication,

the recent discussion by F. Canali de Rossi, 'Q. Minucio Termo e il culto di Sarapide a Delo', Labeo 46 (2000), 72-82, with the earlier bibliography.

${ }^{14}$ K.J. Rigsby, Asylia. Territorial Inviolability in the Hellenistic World (Berkley - Los Angeles - London 1996), 580-586.

${ }^{15}$ Rigsby 1996, op.cit. (n. 14), 1-33; M. Dreher, 'Das Asyl in der Antike von seinen griechischen Ursprüngen bis zur christlichen Spätantike', Tyche (1996), 7996; id., 'Asylia und verwandte Begriffe in der griechisch-römischen Antike', in: M. Jung et al. (eds.), Die Sprache des Migrationsdiskurses (Opladen 1997), 36-44; cf. A. Chaniotis, 'Conflicting Authorities. Asylia between Secular and Divine Law in the Classical and Hellenistic Poleis', Kernos 9 (1996), 65-86.

${ }_{16}$ Rigsby 1996, op.cit. (n. 14), 580-586; cf. K. Buraselis, 'Zur Asylie als außenpolitischem Instrument in der hellenistischen Welt', in: M. Dreher (ed.), Das antike Asyl. Kultische Grundlagen, rechtliche Ausgestaltung und politische Funktion (Cologne - Weimar - Vienna 2003), 143-160. 
performed in a designated space. ${ }^{17}$ The Romans had a different understanding of the Greek ritual. For them asylum was temporary refuge from civil law, and it is for this reason that they intervened. Tacitus (Annales 3.60.1-3) comments:

For throughout the Greek cities there was a growing laxity, and impunity, in the creation of rights of asylum. The temples were filled with the dregs of the slave population; the same shelter was extended to the debtor against his creditor and to the man suspected of a capital offence; nor was any authority powerful enough to quell the factions of a race which protected human felony equally with divine worship. It was resolved, therefore, that the communities in question should send their charters and deputies to Rome. A few abandoned without a struggle the claims they had asserted without a title: many relied on hoary superstitions or on their services to the Roman nation. It was an impressive spectacle which that day afforded, when the senate scrutinized the benefactions of its predecessors, the constitutions of the provinces, even the decrees of kings whose power antedated the arms of Rome, and the rites of the deities themselves, with full liberty as of old to confirm or change (transl. Clifford H. MOORE).

Tacitus implies that the Romans decided whether a sanctuary's asylum should be recognized or not primarily on the basis of political criteria: existing treaties and the services done by the applicants to the Roman people. Here, we observe a double dynamic of ritual: on the one hand in the political interpretation of a religious institution, on the other in the replacement of a traditional religious authority (divine oracles) with an external one.

In the case of asylia, the Romans only confirmed or abolished existing privileges. In other cases, their agency consisted in awarding privileges that affected the rituals of communities. The neokoreia, that is, the right to erect a temple to the emperor and consequently to hold the celebrations of the Imperial cult in a province, was a privilege which only the emperor could grant. ${ }^{18}$ It became subject to

${ }^{17}$ F.S. Naiden, 'Supplication and the Law', in: E.M. Harris - L. Rubinstein (eds.), The Law and the Courts in Ancient Greece (London 2004), 71-91; A. Chaniotis, 'Die Entwicklung der griechischen Asylie: Ritualdynamik und die Grenzen des Rechtsvergleichs', in: L. Burckhardt - K. Seybold - J. von UngernSternberg (eds.), Gesetzgebung in antiken Gesellschaften. Israel, Griechenland, Rom (Berlin 2007), 233-246.

${ }^{18}$ B. Burrell, Neokoroi: Greek Cities and Roman Emperors (Boston - Leiden 2004), with further bibliography. 
competition among the Greek communities, exactly like asylia. The introduction of the cult of a living emperor in a city was also subject to approval, at least in the early Empire. The correspondence between the emperor Tiberius and the city of Gytheion on precisely this matter is a good example. In $15 \mathrm{CE}$, Gytheion organised a festival to honour the emperors and the local benefactors Eurykles and Lakon; the first day was dedicated to Augustus, the second to Tiberius, the third to Livia, the fourth to Germanicus, the fifth to Drusus, the sixth to Titus Quinctius Flamininus, the seventh to the memory of C. Iulius Eurykles, and, finally, the last day to C. Iulius Lakon. ${ }^{19}$ The relevant document is characterised as a hieros nomos, a sacred law, which had higher status than a decree or another law. ${ }^{20}$ If we only had this text, we would conclude that the city had unlimited sovereignty in these matters. A second inscription preserves, however, Tiberius' response to the city's request to bestow upon him divine honours and shows that the city's decision was subject to approval: $^{21}$

The envoy you sent to me and to my mother, Decimus Tyrannius Nikanor, delivered to me your letter, to which were attached the laws

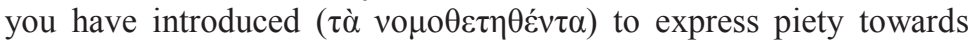
my father and to honour me.

The emperor praises the Gytheians for their gratitude towards Augustus, but then declines the honours offered to him, that is, he rejects the laws introduced by the Gytheians:

${ }^{19}$ SEG XI 923.

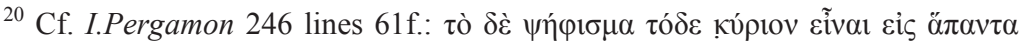

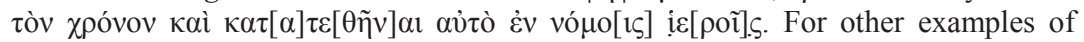
hieroi nomoi with a higher status than other laws, see I.Pergamon 248 and LSCG Suppl. 45 line 69.

${ }^{21}$ SEG XI 922. The inscription contains the fragmentary end of a civic document, a law with superior status over other documents (lines 5-10: [--- है] $] \sigma \varepsilon \sigma \theta \alpha$ l

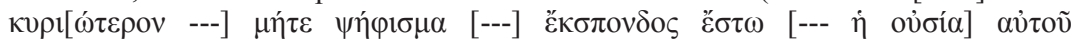

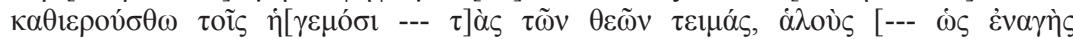

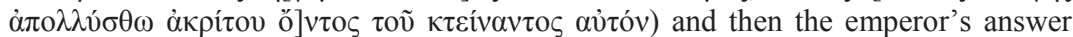

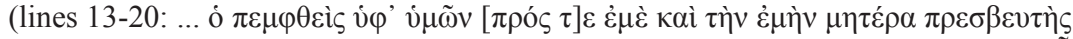

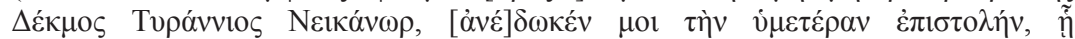

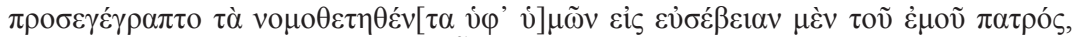

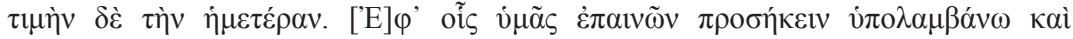

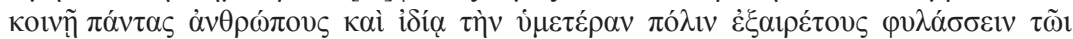

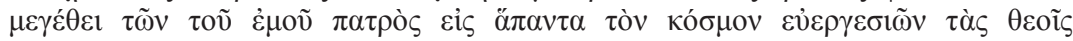

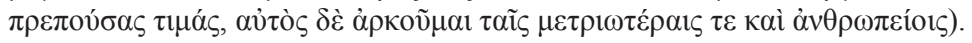


As for me, I am well content with more moderate honours, appropriate to mortals.

Ritual agency has hardly been studied in the context of the Imperium Romanum, although Roman legislation and Roman authority did make a difference in the development of rituals in the Empire. The Romans may have been tolerant of foreign cults and local religious traditions, but their tolerance had limits, as the worshippers of Dionysos in Rome, the Druids, the Jews, and the Christians found out in different ways and on different occasions. Although the legal sources make only rather general statements concerning cults beyond the officially recognised worship - at least until the beginning of the prosecution of the Christians ${ }^{22}$-, yet the intervention of Roman authorities in ritual practices can be observed in countless cases. Such interventions did not have to be as radical as the prohibition of circumcision under Septimius Severus, or in the case of other measures that clearly discriminated against the Jews. ${ }^{23}$ Even the recommendation of Hadrian to the elite of the free city of Aphrodisias that the high priests give money for the construction of an aqueduct rather than for gladiatorial combats, ${ }^{24}$ or the edict of the governor of Macedonia L. Memmius Rufus (c. 100-150 CE), by which he took 1000 denarii originally donated by a benefactor for a Dionysiac procession and added it to the gymnasium fund, ${ }^{25}$ were in

22 R. Haensch, 'Religion und Kulte im juristischen Schrifttum und in rechtsverbindlichen Verlautbarungen der Hohen Kaiserzeit', in: D. Elm von der Osten - J. Rüpke - K. Waldner (eds.), Texte als Medium und Reflexion von Religion im römischen Reich (Stuttgart 2006), 233-247.

${ }^{23}$ On Roman measures concerning the Jews see more recently E. Baltrusch, Die Juden und das römische Reich. Geschichte einer konfliktreichen Beziehung (Darmstadt 2002); cf. the collection of studies by A.M. Rabello, The Jews in the Roman Empire: Legal Problems, from Herod to Justinian (Aldershot 2000).

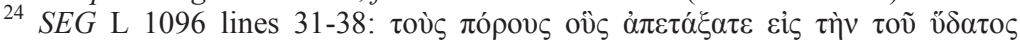

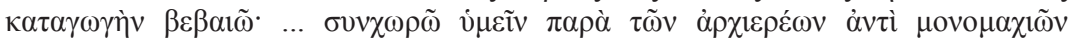

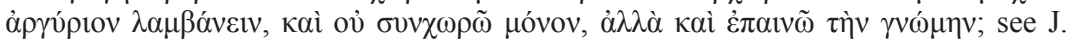
Reynolds, 'New Letters from Hadrian to Aphrodisias: Trials, Taxes, Gladiators, and an Aqueduct', Journal of Roman Archeology 13 (2000), 5-20; A. Chaniotis, 'Macht und Volk in den kaiserzeitlichen Inschriften von Aphrodisias', in: G. Urso (ed.), Popolo e potere nel mondo antico (Pisa 2005), 57f.

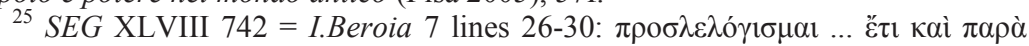

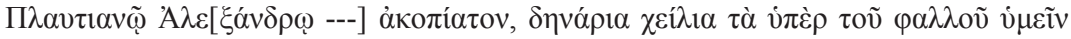

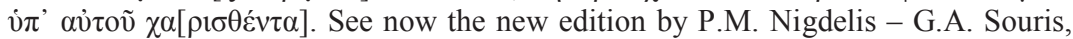

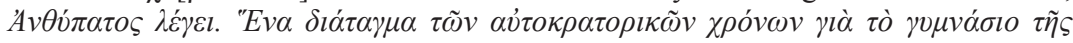
Bépolas (Thessaloniki 2005). 
fact interventions in ritual practices. Finally, an emperor could also introduce new rituals, as Hadrian did, when he deified his young friend Antinoos. The deification of Antinoos throughout the East was connected with the introduction of a mystery cult in Bithynion, Antinoos' city of origin, and in Mantineia, allegedly Bithynion's mother city. ${ }^{26}$

Beyond the authority of the emperor and the representatives of Rome in the provinces, we may observe another significant change in ritual agency in the Roman Empire: the mobility of the divine word. I am not referring to the diffusion of the sacred scripture of the Jews and the Christians - the first started earlier than the Roman Empire, and the second was only occurring during the Imperial period. I am referring to the dissemination of divine oracles - the Sibylline oracles being the best known example. ${ }^{27}$ I will briefly treat two oracles directly connected with ritual practices. The first is an oracular lex sacra from Lindos, stressing the priority of the purity of the mind over that of the purity of the body ${ }^{28}$ The first line is taken from a metrical oracle also found in Epidauros: "You shall be pure inside the temple that smells of incense". Lines two and three are taken from a Sarapis oracle also preserved in a manuscript in Vienna: "Come here with clean hands and with a pure mind and with a true tongue. Clean not through washing, but pure in mind". This is an interesting example of dissemination of ritual texts. Far more famous and directly connected with ritual practices was another oracle: the theosophical oracle of Apollo Klarios, known both from an

${ }^{26}$ On Antinoos' cult see H. Meyer, Antinoos. Die archäologischen Denkmäler unter Einbeziehung des numismatischen und epigraphischen Materials sowie der literarischen Nachrichten (Munich 1991); on his mysteries see most recently P. Goukowsky, 'Sur une épigramme de Thespies', in: J. Dion (ed.), L'épigramme de l'Antiquité au XVIIe siècle ou Du ciseau à la pointe (Nancy 2002), 232-238.

${ }^{27}$ D.S. Potter, Prophecy and History in the Crisis of the Roman Empire (Oxford 1990), 95-140.

${ }^{28}$ LSCG Suppl. 108. Discussion: A. Chaniotis, 'Reinheit des Körpers - Reinheit der Seele in den griechischen Kultgesetzen', in: J. Assmann - T. Sundermeier (eds.), Schuld, Gewissen und Person (Gütersloh 1997), 163; cf. I. Petrovic - A. Petrovic, 'Look Who is Talking Now! Speaker and Communication in Metrical Sacred Regulation', in: E. Stavrianopoulou (ed.), Rituals and Communication in the Graeco-Roman World (Liège 2006), 151-179 (esp. 157 no. 8). 
inscription at Oinoanda and from literary sources. ${ }^{29}$ Apollo speaks and gives a definition of god:

Borne of itself, untaught, without a mother, unshakeable, not contained in a name, known by many names, dwelling in fire, this is god. We, his angels, are a small part of god. To you who ask this question about god, what his essential nature is, he has pronounced that aether is god who sees all, gazing upon whom you should pray at dawn, looking towards the sunrise.

For many worshippers of traditional religion it must have been as shocking to learn from Apollo that the traditional gods were only messengers, and a small part of a motherless polyonymous god, as it was for Julian two centuries later to learn, again from Apollo, that his oracle was no more.

What was the impact of this oracle? Stephen Mitchell has plausibly associated this oracle and its ritual prescription ("gaze at the sun and pray at dawn, looking towards the sunrise") with the cult of Theos Hypsistos. ${ }^{30} \mathrm{He}$ has further argued that the theosebeis, i.e., gentiles who attended the Jewish synagogue, should be identified with the worshippers of Theos Hypsistos (hypsistarii, hypsistiani). The old gods were integrated into this worship as angels of the one

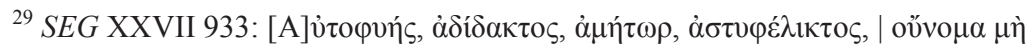

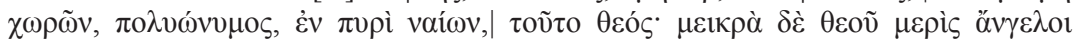

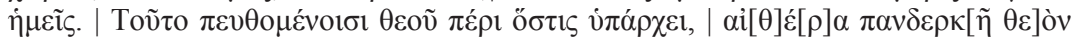

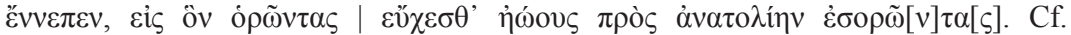
Theosophia Tubigensis $\S 13$ lines 105-108 (Theosophorum Graecorum Fragmenta p. 8-9 ed. Erbse); Lactantius, Divinae Institutiones 1.7.1. See L. Robert, 'Un oracle gravé à Oinoanda', Comptes Rendus de l'Académie des Inscriptions et Belles-Lettres (1971), 597-619 = Opera Minora Selecta V (Amsterdam 1989), 617-639; A.S. Hall, 'The Klarian Oracle at Oenoanda', Zeitschrift für Papyrologie und Epigraphik 32 (1978), 263-268; Potter 1990, op.cit. (n. 27), 351-355; E. Livrea, 'Sull'iscrizione teosofica di Enoanda', Zeitschrift für Papyrologie und Epigraphik 122 (1998), 9096; S. Mitchell, 'The Cult of Theos Hypsistos between Pagans, Jews, and Christians', in: P. Athanassiadi - M. Frede (eds.), Pagan Monotheism in Late Antiquity (Oxford 1999), 83-91, 98, 102, 143 no. 233; R. Merkelbach - J. Stauber, Steinepigramme aus dem griechischen Osten. Band 4. Die Südküste Kleinasiens, Syrien und Palaestina (Munich - Leipzig 2002), 16-19; G. Petzl, 'Zum religiösen Leben im westlichen Kleinasien: Einflüsse und Wechselwirkungen', in: E. Schwertheim - E. Winter (eds.), Religion und Region. Götter und Kulte aus dem östlichen Mittelmeerraum (Bonn 2003), 99f.; A. Busine, Paroles d'Apollon. Pratiques et traditions oraculaires dans l'antiquité tardive (IIe-VIe siècles) (Leiden 2005), 35-40, 203-208, 423.

${ }^{30}$ Mitchell 1999, op.cit. (n. 29) and id., 'Wer waren die Gottesfürchtigen?', Chiron 28 (1998), $62 \mathrm{f}$. 
god. He also suggested that this monotheistic worship, which was strongly influenced by Judaism, was widely diffused in the Mediterranean. Although I am not convinced that every single dedication to Theos Hypsistos in every site of the Mediterranean was made by a theosebes ${ }^{31}$ and I do not agree with the characterisation of this worship as monotheistic, ${ }^{32}$ there can be little doubt that the oracle of Apollo had an impact on worship, and not only in Asia Minor. A dedication from Amastris, explicitly dedicated to Theos Hypsistos, may indeed be an allusion to this oracle: ${ }^{33}$

Upon command of the god with the long hair [i.e., Apollo] this altar [has been erected] of the highest god, who has power over everything, who cannot be seen, but who observes evil deeds, so that plagues of man can be driven away from mortals.

This dedication was made upon command of an oracle of Apollo. The nature of this supreme god is described in terms similar to those in the theosophical oracle: the highest god has power over everything; he cannot be seen, but observes everything. But the $\beta \rho о \tau o \lambda o r \gamma \varepsilon \dot{\alpha} \alpha \delta \varepsilon \dot{\mu} \alpha \tau \alpha$ that Theos Hypsistos averts may be an allusion to the plague during the reign of Marcus Aurelius (cf. below), and in this case the oracle may have been one of the oracles of Apollo Klarios connected with this event.

An essential feature of the cult of Theos Hypsistos was the lighting of fire on altars and lamps. ${ }^{34}$ Numerous bronze objects from the Roman East (dated to the third century CE) have recently been

31 See the objections expressed by M. Stein, 'Die Verehrung des Theos Hypsistos: Ein allumfassender pagan-jüdischer Synkretismus?', Epigraphica Anatolica 33 (2001), 119-126; G.W. Bowersock, 'The Highest God with Particular Reference to North-Pontus', Hyperboreus 8 (2002), 353-362; M. Walraff, 'Pagan Monotheism in Late Antiquity', Mediterraneo Antico 6 (2003), 534f.; W. Ameling, Inscriptiones Judaicae Orientis II. Kleinasien (Tübingen 2004), 13-20.

32 A. Chaniotis, 'Megatheism: The Search for the Almighty God and the Competition between Cults', in: S. Mitchell - P. van Nuffelen (eds.), The Concept of Pagan Monotheism in the Roman Empire (forthcoming).

${ }^{33}$ C. Marek, 'Der höchste, beste, größte, allmächtige Gott. Inschriften aus Nordkleinasien', Epigraphica Anatolica 32 (2000), 135-137 (SEG L 1225, Imperial

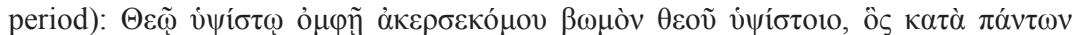

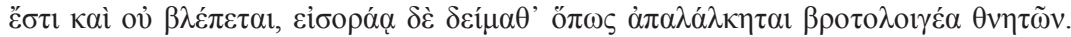
For a discussion of the religious context of this text see Chaniotis forthcoming, op.cit. (n. 32).

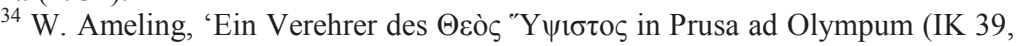
115)', Epigraphica Anatolica 31 (1999), 105-108. 
shown to be lamp hangers used in the cult of Theos Hypsistos

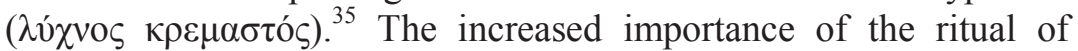
lychnapsia, the lighting of lamps, ${ }^{36}$ must be attributed to the influence of the cult of Theos Hypsistos, which was in its turn associated with Jewish practices. ${ }^{37}$ This made necessary the existence of cult personnel dedicated to this task (lychnaptes, lychnaptria).

An interesting group of inscriptions with the same text in Greek and Latin - a clear indication of the mobility of religious ideas in this period - may also originate in the uncertainties caused by the oracle of Klaros. The text declares that a dedication was made to the gods and goddesses in accordance with the interpretation of an oracle of Apollo Klarios. The Latin version of this text (diis deabusque secundum interpretationem oraculi Clarii Apollinis) is known from ten inscriptions found in Dalmatia, Italy, Sardinia, Numidia,

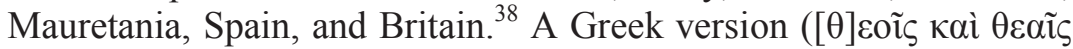

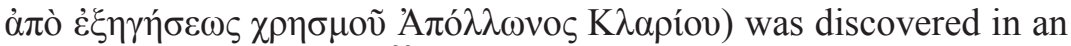
inscription from Pisidia. ${ }^{39}$ Eric BIRLEY, who knew only the Latin inscriptions, associated these dedications with an oracle given during Caracalla's illness in $213 \mathrm{CE}$, Christopher JONES with an oracle of Apollo Klarios recommending measures in order to face the plague that began in $165 \mathrm{CE}^{40}$ Stephen Mitchell (n. 39) has suggested identifying this oracle precisely with the theosophical oracle from Oinoanda. The exegesis may have recommended the worship of the traditional Olympian gods, although they ranked below the highest god. Thus the exegesis would have reconciled traditional religion

${ }^{35}$ N. Franken, 'Lampen für die Götter. Beobachtungen zur Funktion der sogenannten Vexillumaufsätze', Istanbuler Mitteilungen 52 (2002), 369-381.

${ }^{36}$ E.g., I.Leukopetra 39 (cult of Mether Theon, Leukopetra, 193/4 CE); LSAM 28 lines 13f. (cult of Dionysos, Teos, first century CE); IGBulg III 1517 line 30 (cult of Dionysos, Philippopolis, third century); LSCG Suppl. 25 A 6f. (lighting of lamps in the daily service in Epidauros, second/third century). Of cource, the lighting of lamps is already attested earlier in Greek religion; see e.g. SEG XLIII 1186 (Kyrene, 4th cent. BC): $\lambda v \chi v 0 \kappa \alpha i ̈ \alpha$.

${ }^{37}$ One should also consider the influence of Egyptian rituals; see e.g. LSAM 36 lines 13-15.

${ }^{38}$ For the references, see Busine 2005, op.cit. (n. 29), 184 f.

39 S. Mitchell, 'Inscriptions from Melli (Kocaaliler) in Pisidia', Anatolian Studies 53 (2003), 151-155 no. 13 (SEG LIII 1587).

${ }^{40}$ E. Birley, 'Cohors I Tungrorum and the Oracle of the Clarian Apollo', Chiron 4 (1974), 511-513; C.P. Jones, 'Ten Dedications "To the Gods and Goddesses" and the Antonine Plague', Journal of Roman Archeology 18 (2005), 293-301; id., 'Cosa and the Antonine Plague', Journal of Roman Archeology 19 (2006), 368f. 
with the rising popularity of monotheistic tendencies. The occasions envisaged by BIRLEY and JONES explain the existence of an oracle, but not why an interpretation ( $\dot{\varepsilon} \xi \eta \dot{\eta} \gamma \eta \sigma r \varsigma)$ recommending dedications to the gods and the goddesses was necessary. This is why I find MitCHELL's suggestion quite possible. It is conceivable that the priests at Klaros took the initiative of sending Apollo's message to the Latin-speaking parts of the Empire, exactly as Alexander of Abonou Teichos made sure that the oracles of his new god became known (Lucian, Alexander 24).

Even if the cult of Theos Hypsistos did not have the uniformity postulated by Stephen MiTCHELL, the existence of a ritual text (an oracle) issued by a divine authority (Apollo) must have had a substantial impact. How the existence of an empire facilitated the diffusion not only of ritual texts but also of uniform ritual practices can be observed in the case of dispersed communities of worshippers, such as the initiates in mystery cults - Mithraic, Dionysiac, Orphic, Egyptian. The uniform iconography and vocabulary of rituals reflect the existence of uniform traditions, without excluding the possibility of deviations from rules. Sacred landscapes, such as Dionysiac grottos and miniature Niles, were reproduced for the performance of rituals. ${ }^{41}$ The iconography and vocabulary of the mysteries of Mithras, whether in Dura-Europos in Syria or in the Mithraeum of the Church of Santa Prisca in Rome or in the 'Schlangengefäß' from Mainz ${ }^{42}$ reproduce to some extent the same model (e.g., in the designations of initiation grades). More important, the uniform hierarchical structure of Mithraic communities reproduced phenomena of contemporary society, especially relations of patronage. Patterns of hierarchy and

41 Dionysiac grottos: A.-F. Jaccottet, Choisir Dionysos. Les associations dionysiaques ou la face cachée du Dionysisme (Zürich 2003), 150-162. Nilotic landscapes: R. Saldit-Trappmann, Tempel der ägyptischen Götter in Griechenland und an der Westküste Kleinasiens (Leiden 1970), 1-25. On the reproduction of sacred landscapes cf. A. Chaniotis, 'Ritual Dynamics in the Eastern Mediterranean: Case Studies in Ancient Greece and Asia Minor', in: W.V. Harris (ed.), Rethinking the Mediterranean (Oxford 2005), 161f.

${ }^{42}$ R.L. Beck, 'Ritual, Myth, Doctrine, and Initiation in the Mysteries of Mithras: New Evidence from a Cult-vessel', Journal of Roman Studies 90 (2000), 145-180. 
subordination were expressed through ritual performances of 'liberation' and 'abasement'. ${ }^{43}$

Magic is a major ritual activity, and one in which unifying agents were also at work in the Roman Empire. It has been observed that the magical recipes we find in magical papyri were copied and disseminated. Magical formulae found in texts all over the Empire originate in such recipes. ${ }^{44}$ It is only through the existence of such handbooks that we can explain, for example, the wide dissemination of an exorcism aimed at curing the condition known as the wandering womb. ${ }^{45}$ The exorcism addresses the womb of a woman and orders it to curtail its movements, which were believed to cause diseases. The ritual of this exorcism is known from the magical papyri, but also from an amulet in Beirut - the author of which misunderstood the Latin ipsa of the formulary and did not replace it with the personal name of the woman who was to use the amulet ${ }^{46}$ and another amulet in Great Britain; the wording of the exorcism is used in an Aramaic recipe from seventh-century Cairo and it lives on

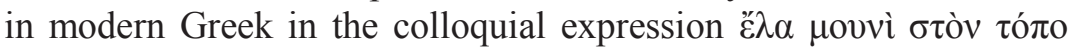
бov.

Another ritual, the diffusion of which cannot be explained without positing instructions given by professional magicians, is the cession of lost property to a god with the request to find and punish the culprit. This practice is attested in magical texts ("prayers for

\footnotetext{
${ }^{43}$ R. Gordon, 'Ritual and Hierarchy in the Mysteries of Mithras', in Antigüedad: Religiones y Sociedades 4 (2001) [2005], 245-274.

${ }^{44}$ C.A. Faraone, 'Handbooks and Anthologies: The Collection of Greek and Egyptian Incantations in Late Hellenistic Egypt', Archiv für Religionsgeschichte 2 (2000), 195-214. D.R. Jordan has discussed several such cases: D.R. Jordan - R. Kotansky, 'Magisches. 338. A Solomonic Exorcism. 339. A Spell for Aching Feet', in: M. Gronewald et al., Kölner Papyri (P.Köln.). Band 8 (Opladen 1997) 63-69; D.R. Jordan, 'Notes on Two Michigan Magical Papyri', Zeitschrift für Papyrologie und Epigraphik 136 (2001), 183-193; id., 'Intrusions into the Text of the Amulet P.Kellis G. I 87?', Zeitschrift für Papyrologie und Epigraphik 137 (2001), 34; id., 'Magia nilotica sulle rive del Tevere', Mediterraneo antico 7.2 (2004), 693-710; id. 'Three Notes', Zeitschrift für Papyrologie und Epigraphik 152 (2005), 156.

45 The material has been collected by C.A. Faraone, 'New Light on Ancient Greek Exorcisms of the Wandering Womb', Zeitschrift für Papyrologie und Epigraphik 144 (2003), 189-197.

${ }_{46}$ R. Kotansky, Greek Magical Amulets: The Inscribed Gold, Silver, Copper, and Bronze Lamellae. Part I. Published Texts of Known Provenance (Opladen 1994), 265-269 no. 51.
} 
justice'), 'confession inscriptions', and dedications. ${ }^{47} \mathrm{~A}$ tablet, probably from Lydia, is a good example: ${ }^{48}$

I dedicate to you, Mother of the Gods, all the golden objects which I have lost; in order that she (the goddess) will investigate (the matter) and reveal everything, and in order that those who possess them will be punished in a manner worthy of her power, so that she (the goddess) will not look ridiculous.

The victim was probably a woman, who not only suffered the loss of gold objects, but also the loss of face. In order to motivate the goddess to act, she transferred the loss of face to the goddess, thus urging her to reveal her power. The goddess became the victim of the theft and was forced to punish the culprit. This procedure is known from many texts, from Asia Minor to Britain, that record the permanent transmission of property claims from a mortal to a divinity. In a dedication from Kula (176 CE) a woman who had been cheated during a transaction reports: ${ }^{49}$

I have bought [---], but having been treated disdainfully, I have 'ceded' them to Mes Axiottenos, so that he can do with them as he pleases.

The same ritual act of cession is also attested in Macedonia, in the sanctuary of the Mother of Gods at Leukopetra (near Beroia). One of the inscriptions found there records the donation of a lost female

${ }^{47}$ See A. Chaniotis, 'Under the Watchful Eyes of the Gods: Aspects of Divine Justice in Hellenistic and Roman Asia Minor', in: S. Colvin (ed.), The Greco-Roman East. Politics, Culture, Society (Cambridge 2004), 15-19; id., 'Ritual Performances of Divine Justice: The Epigraphy of Confession, Atonement, and Exaltation in Roman Asia Minor', in: H. Cotton et al. (eds.), From Hellenism to Islam: Cultural and Linguistic Change in the Roman Near East (Cambridge 2009), 115-153.

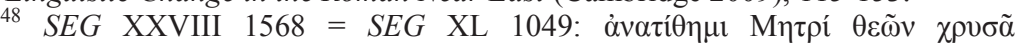

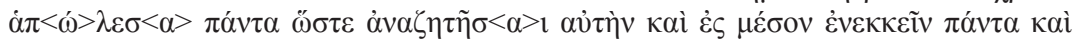

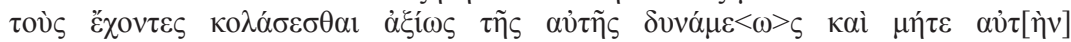
$\kappa \alpha \tau \alpha \gamma \varepsilon \dot{\lambda} \alpha \sigma \tau$ ov $\varepsilon \sigma \varepsilon \sigma \theta[\alpha 1]$. See H.S. Versnel, 'Beyond Cursing: The Appeal to Justice in Judicial Prayers', in: C.A. Faraone - D. Obbink (eds.), Magika Hiera: Ancient Greek Magic and Religion (New York - Oxford 1991) 74; id., 'Writing Mortals and Reading Gods. Appeal to the Gods as a Strategy in Social Control', in: D. Cohen (ed.), Demokratie, Recht und soziale Kontrolle im klassischen Athen (Munich 2002), 55f.; A. Chaniotis, 'Von Ehre, Schande und kleinen Verbrechen unter Nachbarn: Konfliktbewältigung und Götterjustiz in Gemeinden des antiken Anatolien', in: F.R. Pfetsch (ed.), Konflikt (Heidelberg 2004), 247.

${ }^{49}$ H. Malay, Greek and Latin Inscriptions in the Manisa Museum (Vienna

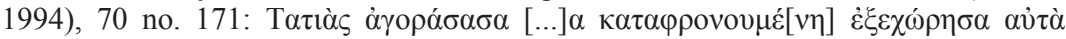

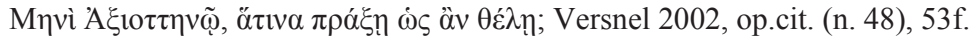


slave by a man, who requested the goddess to look for her and, in case of success, keep her. ${ }^{50}$ That cession was a ceremonial act performed in sanctuaries and recorded by priests. It can be inferred from a text from Saguntum (first century CE). ${ }^{51}$ A slave (Chryse), who was the victim of theft by another slave, invoked Iao and donated to him the stolen money (rogat et a Iau dat pecunia quae a me accepit Heracla), expecting the god to punish the thief. The person imposing the curse promised a reward to a cult functionary for his services (do pecuniam onori sacricola). Finally, cession is attested in many British curse tablets. I only quote one example from London (third century CE) $:^{52}$

I give to the goddess Diana my headgear and band less one-third. If anyone has done this, I give him, and through me let him be unable to live.

\section{Ritual Transfer}

A dedicatory relief of unknown provenance, from somewhere in the Near East (third or second century BC), shows a priest in Oriental dress burning incense. ${ }^{53}$ The tradition of worshipping the gods by burning incense on a thymiaterion or a pyre is Semitic. But the priest, with the very Greek name Philotas, is not standing in front of the statue of an Oriental god, but in front of a statue of Herakles, represented according to the standard Greek iconographic tradition. Herakles, notorious for his good appetite, would never have appreciated such an offering in a Greek sanctuary; in Greece, he demanded the sacrifice of animals - occasionally demanding for himself not just a thigh but the ninth part of the animal. This example demonstrates the complex nature of phenomena of syncretism and cult transfer. Are we dealing with a Greek worshipping a Greek god in an Oriental manner? Or with an Oriental who has adopted the Greek iconography for his god, a Greek name for himself, and the

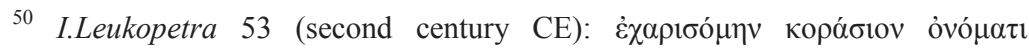

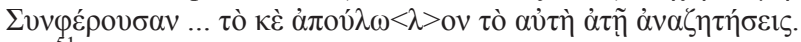

51 J. Corell, 'Invocada la intervención de Iau en una defixio de Sagunto (Valencia)', Zeitschrift für Papyrologie und Epigraphik 130 (2000), 241-247.

${ }_{52}$ R.S.O. Tomlin - M.W.C. Hassall, 'Inscriptions', Britannia 34 (2003), 363.

${ }^{53}$ P. Bordreuil - P.-L. Gatier, 'Le relief du prêtre Philôtas', Syria 67 (1990), 329-338. 
Greek language for his dedication? No matter how we answer this unanswerable question, it is nevertheless clear that we are confronted with a phenomenon of ritual dynamics: the performance of a ritual outside of its traditional context.

If similar phenomena abound in the Roman Empire, it is because of the increased mobility that the Empire made possible: the involuntary mobility of captives and slaves; the individual mobility of the trader and the artisan; the planned mobility of colonisation; the institutionalised mobility of the representatives of imperial authority - the army, and the staff of the provincial administration. The transfer of rituals took place through different channels and took a variety of forms precisely because the forms of mobility were so diverse.

The introduction of new cults is, of course, not a new phenomenon under the Roman Empire. I cannot think of any area eventually integrated into the Imperium Romanum that did not witness the introduction of a foreign cult or was not influenced by foreign cults already before the establishment of Roman rule. Yet the mobility of persons and ideas under the Roman Empire enhanced this process. The introduction of the cult of a god - or the attribution of a new epithet or aspect to a traditional god - did not necessarily also mean the introduction of a new ritual. People in a small Syrian town might worship a god called by the Greek name Zeus without necessarily offering a sacrifice according to Greek rite. So it is necessary to make a distinction between cult transfer and ritual transfer.

Ritual transfer occurred in the Roman Empire in two different ways: in a geographical sense, i.e., the transfer of rituals from one region to another; ${ }^{54}$ and in a metaphorical sense, from one context to

54 Some aspects of this subject were studied in the project "Römische Reichsreligion und Provinzialreligion"; see J. Rüpke (ed.), Antike Religionsgeschichte in räumlicher Perspektive (Tübingen 2007); see also C. Ando, The Matter of the Gods: Religion and the Roman Empire (Berkeley 2008), 100-105. A good example is offered by the diffusion of the Egyptian and oriental mystery cults and their rituals; see L.Bricault, Atlas de diffusion des cultes isiaques (Paris 2001); id., Recueil des inscriptions concernant les cultes isiaques (Paris 2005); C. Bonnet et al. (eds.), Religions orientales - culti misterici: Neue Perspektiven nouvelles perspectives - perspettive nuove (Stuttgart 2006); L. Bricault et al. (eds.), Nile into Tiber: Egypt in the Roman World (Leiden 2007). On the paradigm of sacrificial rituals in Asia Minor see G. Schörner, 'Opferritual und Opferdarstellung: Zur Struktuierung der Zentrum-Peripherie-Relation in Kleinasien', in: H. Cancik et 
another. A characteristic example of the first category is the wide diffusion of the Roman funerary ritual of the rosalia, the annual adornment of the grave with roses. ${ }^{55}$ This custom took place on the occasion of the Roman festival of the Rosalia (or Rosae or Rosatio), devoted to the commemoration of the deceased and mostly celebrated by families and burial associations in May. In the Greek East it is attested under the name of $\dot{\rho}$ ó $\alpha$ or $\dot{\rho}$ o $\delta 1 \sigma \mu$ ó ${ }^{56}{ }^{56}$ It was probably first brought by Roman and Italian settlers to the Balkans, and was very soon imitated by the local populations there and further East, since it could easily be associated with the traditional custom of bringing flowers to the grave.

Another example is the introduction of the rituals of the Roman festival of the Compitalia in Delos in the late second century BC. ${ }^{57}$ Here, the Compitalia were celebrated in front of the houses and in the neighbourhoods of Italian families, where private sacrifices to the Lares, Mercurius, and Hercules were offered. Although the festival had an official character, as a festival of the community of the Italici, it was nevertheless also adopted by persons of a different ethnic origin, namely the freedmen of the Italian families. The athletic competitions, the $l u d i$, and the sacrifices were part of the original tradition; but the custom of erecting altars in front of the houses was a Greek tradition adopted by the Italian settlers.

The establishment of Roman colonies throughout the Empire meant the performance of the same rituals during the foundation of each city as well as the copying of the religious institutions of Rome, even though the new cultic traditions often merged with the local ones as Nicole BELAYCHE has recently demonstrated. ${ }^{58}$ In addition to the institutionalised transfer of rituals by larger groups of settlers like

al. (eds.), Zentralität und Religion. Zur Formierung urbaner Zentren im Imperium Romanum (Tübingen 2006), 69-94.

${ }^{55}$ C. Kokkinia, 'Rosen für die Toten im griechischen Raum und eine neue rodismos-Inschrift aus Bithynien', Museum Helveticum 56 (1999), 204-221.

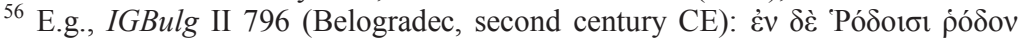

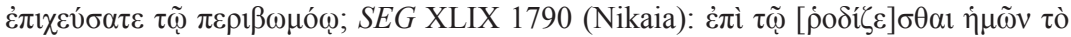

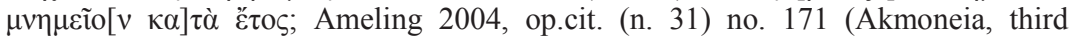

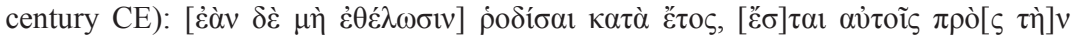

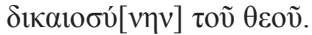

57 See the excellent treatment by C. Hasenohr, 'Les Compitalia à Délos', Bulletin de Correspondance Hellénique 127 (2003), 167-249.

${ }^{58}$ N. Belayche, 'Les formes de religion dans quelques colonies du ProcheOrient', Archiv für Religionsgeschichte 5.1 (2003), 157-179. 
Roman colonists - the Jewish diaspora being the best known phenomenon of this type - the mobility of individuals could also contribute to the mobility of rituals. When a senator from Perge founded a sanctuary at Panoias in Portugal, he wrote some of the ritual prescriptions in Greek. ${ }^{59}$ The ritual prescriptions for the cult of Mes in Athens were introduced by immigrants. ${ }^{60}$ When a Phrygian died at Dyrrhachion in Epirus, the funerary imprecation written on his grave used a typical formula known from his country: "the violator should lose his own children in foreign lands". ${ }^{61}$

A curse formula is not simply a text; it is a performative ritual text, and requires the performance of a ritual, even if this ritual does not have to be very elaborate and it may be as simple as raising both hands towards the sun and uttering the words. The diffusion of the same iconography of ritual gestures throughout the Empire implies the diffusion of the rituals in which these gestures found application, exactly as the diffusion of the same vocabulary implies the diffusion of ritual practices. I have already mentioned the dissemination of the custom of lighting altars and lamps. Another ritual that gained great popularity was hymnody. ${ }^{62}$ Alexander, the false prophet of Abonou Teichos, requested through an oracle that the cities of Paphlagonia and Pontos send choruses of boys. ${ }^{63}$ Hymnodoi were sent by various cities to the oracle of Apollo at Klaros. ${ }^{64}$ In Stratonikeia and Teos, new decrees were passed mandating the singing of hymns on a

59 G. Alföldy, 'Die Mysterien von Panóias/Vila Real, Portugal', Madrider Mitteilungen 38 (1997), 176-246.

${ }^{60}$ LSCG 55; E. Lane, Corpus Monumentorum Religionis Dei Menis. I. The Monuments and Inscriptions; EPRO 19 (Leiden 1971), 9f.; G.H.R. Horsley, New Documents Illustrating Early Christianity. A Review of the Greek Inscriptions and Papyri Published in 1978 (Alexandria 1983), no. 6.

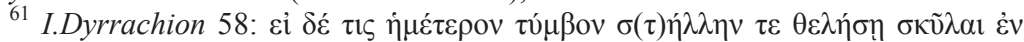

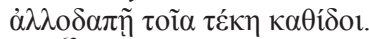

${ }^{62}$ Cf. S. Bradbury, 'Julian's Pagan Revival and the Decline of Blood Sacrifice', Phoenix 49 (1995), 331-356.

${ }^{63}$ Lucian, Alexander 41; U. Victor, Lukian von Samosata, Alexander oder Der Lügenprophet. Eingeleitet, herausgegeben, übersetzt und erklärt (Leiden - New York - Cologne 1997), 49f. and 159f.; A. Chaniotis, 'Old Wine in a New Skin: Tradition and Innovation in the Cult Foundation of Alexander of Abonouteichos', in: E. Dabrowa (ed.), Tradition and Innovation in the Ancient World (Kraków 2002), $76 \mathrm{f}$.

${ }^{64}$ L. and J. Robert, La Carie. Histoire et géographie historique avec le recueil des inscriptions antiques. Tome II. Le plateau de Tabai et ses environs (Paris 1954), 115-119; SEG XXXVII 961-980. 
monthly and daily basis respectively. ${ }^{65}$ Several of the metrical oracles of Klaros recommend the singing of hymns, ${ }^{66}$ which was also practiced in the cult of the emperor. ${ }^{67}$

At the border between prayer and magic Henk VERSNEL has placed a particular group of texts designated as 'prayers for justice'. ${ }^{68}$ Their most important difference from normal curses is the fact that the imposer of the curse justifies his actions, persuading and not forcing the avenging divinity to act. Prayers for justice make their first appearance in the third century $\mathrm{BC}^{69}$ and remain very rare in the Hellenistic period. Their wide dissemination in the Imperial period is another example of ritual transfer.

The second category of ritual transfer is not connected with a geographical displacement or diffusion but with a change of context. The best example is the imperial cult, the rituals of which were to a great part modelled on the rituals of the worship of the gods - with celebrations on the birthday of the emperor, processions, the carrying of statues (cf. the office of the sebastophoros), sacrifices, the singing of hymns, prayers, banquets, contests, and possibly mysteries. ${ }^{70}$ Although there are many similarities between the Hellenistic ruler

${ }^{65}$ LSAM 69; I.Stratonikeia 1101.

66 R. Merkelbach - J. Stauber, 'Die Orakel des Apollon von Klaros', Epigraphica Anatolica 27 (1996), 1-54 nos. 2, 4, and 11; cf. F. Graf, 'An Oracle Against Pestilence from a Western Anatolian Town', Zeitschrift für Papyrologie und Epigraphik 92 (1992), 267-279.

${ }^{67}$ A. Chaniotis, 'Der Kaiserkult im Osten des Römischen Reiches im Kontext der zeitgenössischen Ritualpraxis', in: Cancik - Hitzl 2003, op.cit. (n. 9), 3-28.

${ }^{68}$ Versnel 1991, op.cit. (n. 48), 68-75, 81-93; Versnel 2002, op.cit. (n. 48), 4850. Cf. G. Björck, Der Fluch des Christen Sabinus (Uppsala 1938); D. Jakov - E. Voutiras, 'Gebet, Gebärden und Handlungen des Gebetes', in: Thesaurus Cultus et Rituum Antiquorum III (Los Angeles 2005), 129f. ('Rachegebet').

${ }^{69}$ Two early clear cases of 'prayers for justice': R. Wünsch, Defixionum Tabellae Atticae. IG III.3. Appendix (Berlin 1897), no. 102 (Athens, third century BC?); SEG XLVII 510 (Oropos, late third century BC).

${ }^{70}$ On the rituals of the imperial cult in the East see S.R.F. Price, Rituals and Power. The Roman Imperial Cult in Asia Minor (Cambridge 1984); Chaniotis 2003, op.cit. (n. 67), 3-28. The existence of mysteries of the Imperial cult was inferred from the office of the sebastophantes, but J. Strubbe, The Inscriptions of Pessinous. IK 66 (Bonn 2005), 24, 33 and id., 'The Imperial Cult at Pessinous', in: L. de Blois - P. Funke - J. Hahn (eds.), The Impact of Imperial Rome on Religions, Ritual and Religious Life in the Roman Empire: Proceedings of the Fifth Workshop of the International Network Impact of Empire, Münster 2004 (Leiden 2006), 116-119, has recently argued that the sebastophantes was responsible for showing statues on emperors during processions. 
cult, as it was practiced in the poleis, and the imperial cult, we can still observe significant differences, such as the latter's performance by provincial and other koina, new types of spectacles (gladiatorial combats and venationes), the singing of hymns by hymnodoi, ${ }^{71}$ the carrying of the images of emperors in processions, ${ }^{72}$ and the performance of prayers not only for the well-being of the emperor, ${ }^{73}$ but indeed addressed to the emperor. ${ }^{74}$

\section{Ritual Emulation and Competition}

A strong motivation for ritual transfer comes from envy and a spirit of competition, which together inspire emulation. Here, I am not concerned with competition within a community but with competition among communities. ${ }^{75}$ A letter of Antoninus Pius addressed to Ptolemais but found in Kyrene (153/54 CE) is a telling piece of evidence. The emperor criticises Ptolemais for having

${ }^{71}$ Price 1984, op.cit. (n. 70), 70, 88 with note 43, 90, 105, 118, 209, 247 note 44; H. Halfmann, 'Hymnoden von Asia in Kyzikos', in: E. Schwertheim (ed.), Mysische Studien (Bonn 1990), 21-26; R.E.A. Palmer, 'Paean and Paeanists of Serapis and the Flavian Emperors', in: R.M. Rosen - J. Farrell (eds.), Nomodeiktes. Greek Studies in Honor of Martin Ostwald (Ann Arbor 1993), 355-365. Hymns for Hellenistic kings are known, but are a very peripheral phenomenon: Douris, FGrHist 76 F 13 (Demetrios Poliorketes); I.Erythrai 205 lines 74-76 (Seleukos I).

${ }^{72}$ Price 1984, op.cit. (n. 70) 189f.; M. Clauss, Kaiser und Gott. Herrscherkult im römischen Reich (Stuttgart - Leipzig 1999), 304; Chaniotis 2003, op.cit. (n. 67), 9f.

73 E.g., J. Moralee, 'For Salvation's Sake'. Provincial Loyalty, Personal Religion, and Epigraphic Production in the Roman and Late Antique Near East (New York - London 2004).

${ }^{74}$ This has been a controversial subject, but in addition to the material which I discuss in Chaniotis 2003, op.cit. (n. 67), 19f., we now have further evidence from Keramos. A new inscription (SEG LIII 1210, c. 150-200 CE) commemorates the performance of a prayer by the association of the priests of Theos Sebastos

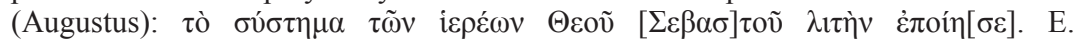
Varinlioglu, 'Die Inschriften von Keramos', in: V. Ruggieri (ed.), Il golfo di Keramos: dal tardo-antico al medioevo bizantino (Soveria Mannelli 2003), 401f., assumed that the priests performed a sacrifice for the well-being of an emperor. Yet since the priests were those of Augustus and not of the current emperor, it is more likely that this priestly board, presumably consisting of all the former priests of Augustus, addressed their prayer to the deified emperor.

${ }^{75}$ Cf. A. Chaniotis, 'Konkurrenz von Kultgemeinden im Fest', in: J. Rüpke (ed.), Festrituale: Diffusion und Wandel im römischen Reich (Tübingen 2008), 6887. 
recently sent a delegation to the Capitolia in Rome for the first time, because such actions caused strife among the poleis: ${ }^{76}$

I am amazed that although you have never sent a delegation and participated in the joint sacrifice at the contest of the Capitolia in the past, you have now sent a delegation for the first time; for you very well know that such innovations cause strife among the cities. The joint sacrifice was offered during the contest on behalf of the ethnos (i.e., of the cities of Kyrenaika).

A roughly contemporary inscription from Aphrodisias honours a generous woman who had served as priestess of the Augusti and stephanephoros. Among other things she offered sacrifices for the health of the emperors; she organised banquets for the entire people; and

she brought for the first time for the thymelic and scenic competitions the best plays in Asia and presented them to the fatherland, so that the neighbouring cities came and participated in the festival in order to attend the performance of the plays. ${ }^{77}$

The celebration of festivals in the Roman Empire contributed to the mobility of traders, actors, entertainers, athletes, and spectators. It also contributed to the mobility of the rituals that were performed in these celebrations.

For a ritual experienced in one place might be admired, discussed, envied, and emulated. Another decree, this time for the benefactor Epameinondas of Akraiphia in Boiotia (c. $40 \mathrm{CE}$ ), explicitly states that his extremely high and continual expenditures were not only admired in his city, but also in the neighbouring cities. $^{78}$ In the Greek world, envy (phthonos) and emulation

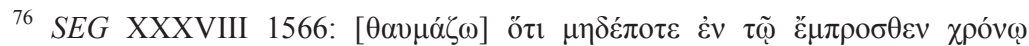

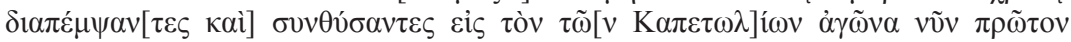

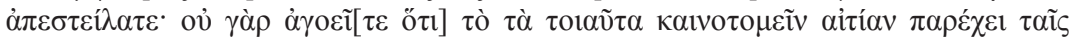

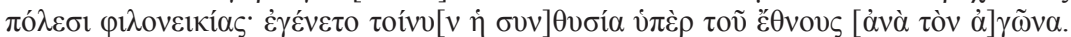
See A. Laronde, 'Les rivalités entre les cités de la Cyrénaïque à l'époque impérial', in: Follet 2004, op.cit. (no. 10), 187-193.

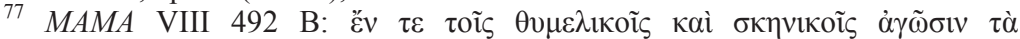

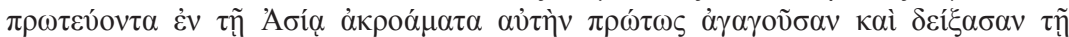

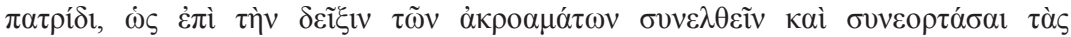

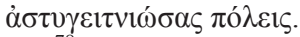

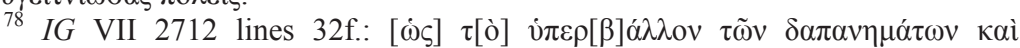

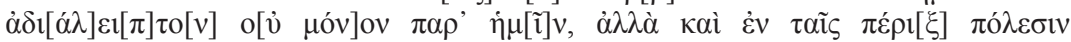

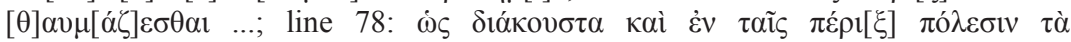


(mimesis) go together, ${ }^{79}$ and a successful ritual would always find imitators. The almost uniform ritual practices in celebrating festivals, honouring athletes and benefactors, organising banquets, etc., are the result of such emulation. This explains, e.g., the foundation of dozens of Pythian festivals in the Balkans and in Asia Minor in the third century CE (27 cases are known), ${ }^{80}$ but also the new 'habit' of the people interrupting the funeral of a benefactor, seizing the body of the deceased, and transforming the family funeral into a public event. ${ }^{81}$ This is attested for the first time in Knidos (late first or early second century CE). ${ }^{82}$ As the death of a descendant of a local benefactor became known, "the people were shocked beyond measure because of her virtue and her reputation". The people then

assembled with great zeal in the theatre [lacuna], while her corpse was being carried out. And after the people had seized her body, they unanimously demanded that they might bury her with the participation of the entire people, and manifested through acclamations her virtue, in order that she receive also after her death the appropriate honours.

This example was soon after followed in another city in Karia, in Aphrodisias, in the early second century CE. Here, too, the people interrupted the family funeral and carried the corpse of Tatia Attalis away in order to bury it in a public ceremony. ${ }^{83}$ Some time later this

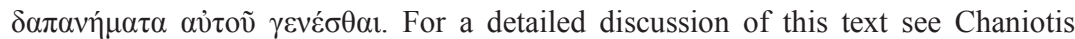
2008, op.cit. (n. 75) and E. Stavrianopoulou's paper in this volume.

${ }^{79}$ E.g., M. Dickie, 'The Topic of Envy and Emulation in an Agonistic Inscription from Oenoanda', in: E. Csapo - M. Miller (eds.), Poetry, Theory, Praxis: The Social Life of Myth, Word, and Image in Ancient Greece. Essays in Honour of William J. Slater (Oxford 2003), 232-246.

${ }^{80}$ R. Weir, Roman Delphi and its Pythian Games (Oxford 2004), 176-211.

${ }^{81}$ This phenomenon was first studied by C.P. Jones, 'Interrupted Funerals', Procedings of the American Philological Association 143 (1999), 588-600; see also A. Chaniotis, 'Rituals between Norms and Emotions: Rituals as Shared Experience and Memory', in: E. Stavrianopoulou (ed.), Rituals and Communication in the Graeco-Roman World (Liège 2006), 223-226.

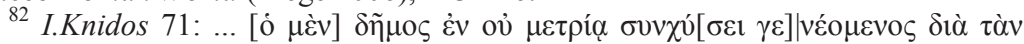

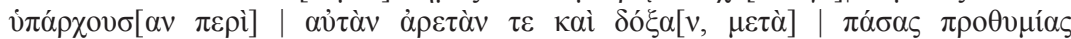

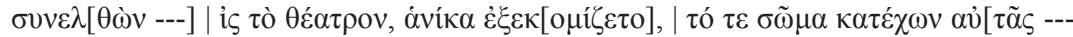

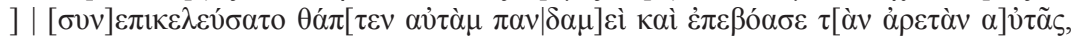

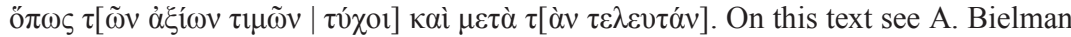
- R. Frei-Stolba, 'Femmes et funérailles publiques dans l'antiquité gréco-romaine', Études de Lettres. Revue de la Faculté des Lettres de l'Université de Lausanne (1998), 5-33.

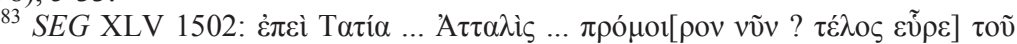

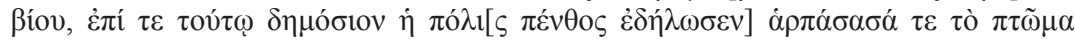


was repeated in Kaunos, ${ }^{84}$ and in 177 CE the burial of Herodes Atticus, which was being performed by his freedmen in Marathon, was interrupted by the Athenian ephebes, who marched from Athens to Marathon, "seized the body with their own hands", brought it back to Athens in procession, and buried it there, near the stadium that Herodes had donated. ${ }^{85}$ By the time of Herodes' death, something that had started as a spontaneous emotional response in one city had become a calculated ritual.

Competition among communities not only caused emulation, and consequently dissemination of rituals; it also caused differentiation, that is, the development of a particular local profile of a cult. There was an Apollo festival in every city, but only Akraiphia celebrated it with the performance of the syrtos-dance $;{ }^{86}$ many cities had festivals of Hera, but only Plataia celebrated it by constructing and burning wooden images, the daidala ${ }^{87}$ every city had a festival of Artemis, but only in Mopsouhestia was the priestess designated as diabetria Perasias and made to walk through fire. ${ }^{88}$ There was no city without a festival of Dionysos; but only one city, perhaps Chalkis, performed a unique ritual: a man was carried on a phallus fifty-five times

ómo $0 v \mu \alpha \delta$ òv [---]. J. Reynolds - C. Roueché, 'The Funeral of Tatia Attalis at Aphrodisias', Ktema 17 (1992) [1996], 153-160.

${ }^{84}$ P. Herrmann, 'Zwei Inschriften von Kaunos und Baba Dag', Opuscula Atheniensia 10 (1971), 36-39.

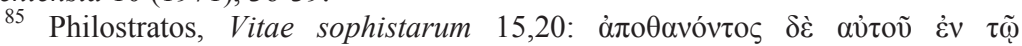

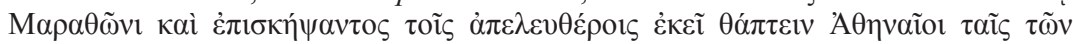

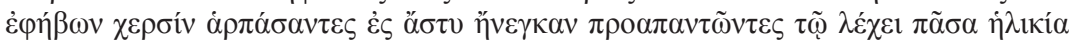

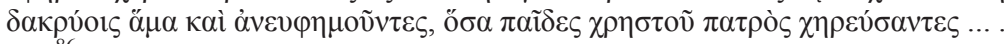

${ }^{86} I G$ VII 2712 , line 66.

${ }^{87}$ D. Knoepfler, 'La fête des Daidala de Platées chez Pausanias: une clef pour l'histoire de la Béotie hellénistique', in: D. Knoepfler - M. Piérart (eds.), Éditer, traduire, commenter Pausanias en l'an 2000. Actes du colloque de Neuchâtel et de Fribourg 1998 (Geneva 2001), 343-374; A. Chaniotis, 'Ritual Dynamics: The Boiotian Festival of the Daidala', in: H.F.J. Horstmanshoff et al. (eds.), Kykeon. Studies in Honour of H.S. Versnel (Leiden - Boston - Cologne 2002), 23-48; J.-Y. Strasser, "La fête des Daidala de Platées et la "Grande Année" d'Oinopidès", Hermes 132 (2004), 338-351; P. Inversen, 'The Small and Great Daidala in Boiotian History', Historia 56 (2007), 381-418.

${ }_{88}$ W.D. Furley, Studies in the Use of Fire in Ancient Greek Religion (Salem 1988), 213-222 (on Strabo 12.2.7); H. Taeuber, 'Eine Priesterin der Perasia in Mopsuhestia', Epigraphica Anatolica 19 (1992), 19-24 (on SEG XLII 1290). 
around the orchestra of the theatre. ${ }^{89}$ Many sanctuaries promised healing, gave oracles, or performed mysteries, but it was only the sanctuary of the snake-god Glykon New Asklepios that combined all three services. ${ }^{90}$ Everywhere in the Empire we encounter designations of cult officials that allude to unique local festivals and rituals. $^{91}$ This too, is an aspect of ritual dynamics in the Roman Empire: the resistance to the trend of homogenisation through the revival of old local rituals (or the invention of pseudo-old rites).

And even in the case of cult communities with an empire-wide diffusion, such as the Dionysiac associations, competition was possible. The members of a Dionysiac association (the Iobakchoi) in Athens stressed through acclamations during a meeting the fact that their club, with its new statutes, would be the best among the Dionysiac associations: ${ }^{92}$

They called out: - Long live our priest Herodes! - Now we are happy!

Now our Bakchus Club is the first among all (Bakchic) clubs!

\section{Beyond 'Romanisation': Cultural Dynamics in the Roman Empire}

This survey of ritual dynamics in the Roman Empire is suggestive and not complete. Focusing on general themes, such as agency, transfer, competition, and emulation, I have attempted to show that the phenomena which one may observe in the Roman Empire are of a paradigmatic value for the study of ritual dynamics in general.

${ }^{89}$ SEG XXIX 807. Cf. P. Veyne, 'Une inscription dionysiaque peu commune', Bulletin de Correspondance Hellénique 109 (1985), 621-624; E. Csapo, 'Riding the phallos for Dionysos', Phoenix 51 (1997), 253-295.

${ }^{90}$ G. Sfameni Gasparro, 'Alessandro di Abonutico, lo "pseudo-profeta" ovvero come construirsi un'identità religiosa. II. L'oracolo e i misteri', in: C. Bonnet - A. Motte (eds.), Les syncrétismes religieux dans le monde méditérranéen antique. Actes du colloque international en l'honneur de Franz Cumont (Brussels - Rome 1999), 275-305; Chaniotis 2002, op.cit. (n. 63).

91 E.g., the pallake at Tralleis; see S.L. Budin, 'Pallakai, Prostitutes, and Prophetesses', Classical Philology 98 (2003), 148-159; the pyrouchos of Demeter in Termessos: SEG LII 1402; the periegetes in Lesbos: IG XII.2.484; various officials who carried objects in processions: Chaniotis 2008, op.cit. (n. 75) 79 note 45; various cult officials in Lydia (e.g. perirantes): M.P. de Hoz, Die lydischen Kulte im Lichte der griechischen Inschriften (Bonn 1999), 87-98.

${ }_{92}$ IG II/III ${ }^{2}$ 1368; LSCG 51; M.-F. Baslez, 'Les notables entre eux. Recherches sur les associations d'Athènes à l'époque romaine', in: Follet 2004, op.cit. (no. 10), 232-234. 
For the ancient historian, the study of ritual dynamics in the Imperium Romanum illuminates aspects of a multifaceted process of change that is only inadequately described as 'Romanisation'. The term 'Romanisation' implies an one-sided relationship between centre (Rome) and periphery (provinces). But as recent research has made clear ${ }^{93}$ and as this article has argued, the religious and cultural changes in the Roman Empire are the result of far more complex processes. To understand them means to abandon the model of the relations between centre and periphery and to re-assess the significance of local traditions, regional competitions, agency, and individual initiatives in the context of an Empire.

Oxford, October 2008

${ }^{93}$ On the model of centre and periphery see the remarks of G. Schörner, 'Opferritual und Opferdarstellung im römischen Kleinasien: Ein Testfall für das Zentrum-Peripherie-Modell', in: De Blois - Funke - Hahn 2006, op. cit. (n. 70), 138-149. On the problems of the concept of 'Romanisation' see e.g. S. Alcock, 'The Problem of Romanization, the Power of Athens', in: M. Hoff - S.I. Rotroff (eds.), The Romanization of Athens: Proceedings of an International Conference, Lincoln/NE 1996 (Oxford 1997), 1-7; G. Woolf, Becoming Roman: The Origins of Provincial Civilization in Gaul (Cambridge 1998), 1-23; J. Webster, 'Creolizing the Roman Provinces', American Journal of Archaeology 105 (2001), 209-225; E.N. Ostenfeld (ed.), Greek Romans and Roman Greeks. Studies in Cultural Interaction (Aarhus 2002); A. Chaniotis, 'What Difference did Rome Make? The Cretans and the Roman Empire', in: B. Forsén - G. Salmeri (eds.), The Province Strikes Back. Imperial Dynamics in the Eastern Mediterranean (Helsinki 2008), 93-96. The situation was different in the West; see J. Scheid, 'Paysage religieux et romanisation. Quelques réflexions en guise de conclusion', in: M. Dondin-Payre - M.-T. RaepsaetCharlier (eds.), Sanctuaires, pratiques cultuelles et territoires civiques dans l'Occident romain (Brussels 2006), 439-448. 